\title{
Literasi Spasial Mahasiswa Calon Guru Sekolah Dasar
}

\author{
Nana Sutarna, Enok Maryani \\ Universitas Pendidikan Indonesia \\ sutarna89@upi.edu
}

\section{Article History}

received 20/11/2021

\begin{abstract}
This study aims to measure the spatial literacy level of students, the research was conducted at STKIP Muhammadiyah Kuningan involving 160 students in the Elementary School Teacher Education study program. Spatial intelligence is an important component developed in learning which can train decision-making skills when facing problems in the surrounding environment. This study uses a quantitative approach with a survey method.. The data collection technique used a survey technique with a Likert scale. The data analysis was carried out using the percentage of data, then interpreting the percentage score and conducting an in-depth analysis. The results of this study indicate that the spatial literacy of elementary school teacher education study program students at STKIP Muhammadiyah Kuningan is in the high category, it is obtained from the spatial literacy percentage score which is $78.73 \%$. This research is also expected to be a study material for other researchers in analyzing and developing students' spatial literacy in learning in higher education in order to support a learning system that can improve students' spatial literacy.
\end{abstract}

Keywords: Spatial Literacy, student, Primary school teachers

\begin{abstract}
Abstrak
Penelitian ini bertujuan untuk mengukur tingkat literasi spasial mahasiswa, penelitian dilakukan di STKIP Muhammadiyah Kuningan dengan melibatkan 160 mahasiswa pada program studi Pendidikan Guru Sekolah Dasar. Kecerdasan spasial merupakan suatu komponen yang penting dikembangkan dalam pembelajaran dimana dapat melatih keterampilan pengambilan keputusan ketika menghadapi permasalahan di lingkungan sekitarnya. Penelitian ini menggunakan pendekatan kuantitatif dengan metode survey. Teknik pengumpulan data menggunakan teknik survey dengan skala likert. Adapun analisis data yang dilakukan adalah menggunakan persentase data, kemudian menginterpretasi skor persentase dan melakukan analisis mendalam. Hasil penelitian ini menunjukkan bahwa literasi spasial mahasiswa program studi pendidikan guru sekolah dasar di STKIP Muhammadiyah Kuningan berkategori tinggi, hal itu didapatkan dari skor persentase literasi spasial tersebut yang berjumlah $78,73 \%$. Berdasarkan kategori tersebut maka tingkat literasi spasial mahasiswa memiliki kategori tinggi. Penelitian ini juga diharapkan dapat menjadi bahan kajian bagi peneliti lain dalam menganalisis dan mengembangkan literasi spasial mahasiswa dalam pembelajaran di perguruan tinggi guna mendukung sistem belajar yang dapat meningkatkan literasi spasial mahasiswa.
\end{abstract}

Kata kunci: Literasi Spasial, mahasiswa, guru sekolah dasar 


\section{PENDAHULUAN}

Perkembangan teknologi, peningkatan kesadaran akan kebutuhan sosial dan ekonomi, serta keanekaragaman budaya mengakibatkan munculnya literasi-literasi baru di berbagai bidang salah satunya literasi spasial. Literasi spasial adalah pengembangan dari proses berpikir spasial untuk meningkatkan pengetahuan dan keterampilan dalam berpikir, bertindak, dan bernalar tentang objek-objek dan hubungan spasial dalam kehidupan sehari-hari dan lingkungan sekitar(Ningsih, 2016) (Ningsih et al., 2021). Kemampuan visual-spasial merupakan salah satu dari sembilan kecerdasan menurut Howard Gardner (Gardner, 2000). Kecerdasan ini diperoleh anak secara bertahap, dimulai dari pengenalan objek melalui persepsi dan aktivitas anak di lingkungannya. Gardner (Santrock, 2007), 2002) menyebutkan bahwa anak-anak dengan kecerdasan visual-spatial yang tinggi cenderung berpikir secara visual. Mereka kaya dengan khayalan internal (internal imagery), sehingga cenderung imajinatif dan kreatif. Kemampuan spasial tidak hanya diperlukan untuk masalah geometri, ataupun pada mata pelajaran biologi, fisika, dan kimia. Akan tetapi, lebih luas lagi, kemampuan spasial dapat membantu seseorang dalam persoalan kehidupan sehari-hari seperti dalam bidang pekerjaan(Setiani, Y., \& Rafianti, 2018) .Kondisi saat ini, terlihat belum banyak yang memiliki minat dalam literasi spasial, kemampuan anak dalam menerjemahkan visualisasi dari gambar dan bangunan ruang bisa diarahkan dalam membangun kecerdasan spasial dengan mengenalkan mereka untuk memahami gambar 2 dan 3 dimensi serta menempatkan aspek keruangan secara tepat dalam pengambilan keputusan. Dorong mereka melakukan eksplorasi fisik keruangan secara aktif. Beri kesempatan anak membuat struktur dan bentukan tertentu seperti mainan lego atau bentuk bangunan lain.

Kemampuan berpikir spasial mulai berkembang di Indonesia. Beberapa penelitian menjelaskan bahwa pembelajaran IPS menggunakan peta dapat meningkatkan spatial literacy siswa SD Lab UPI (Maharani \& Maryani, 2016). Kecerdasan spasial memberikan kemampuan individu dalam menentukan orientasi dan mobilisasi. Kemampuan tersebut dapat direpresentasikan menjadi tiga kemampuan yaitu cognitive maps, cognitive collage, dan spatial mental. Ketiga kemampuan ini merepresentasikan kemampuan manusia untuk menjelajah permukaan bumi dengan cara mentransformasikan berbagai jenis informasi yang didapat dari lingkungan menjadi informasi spasial (Urfan, 2017). Terdapat perbedaan yang mendasar antara kecerdasan spasial dan berpikir spasial. kecerdasan spasial merupakan potensi awal yang dimiliki manusia dalam mengombinasikan ruang beserta komponen yang ada di dalam ruang tersebut. Sedangkan berpikir spasial merupakan kemampuan olah pikir manusia terhadap pengenalan ruang yang dapat berkembang karena mengalami proses input, pengolahan dan output ((Mayalagu, G., Jaafar, M., \& Kuok Choy, 2018). Kecerdasan spasial dianggap kondisi kognitif manusia yang lebih stabil dibandingkan berpikir spasial. Oleh karena itu, pengembangan kemampuan berpikir spasial lebih dibutuhkan dalam menghadapi tantangan persaingan global pada abad 21 ((Aliman, M., \& Mutia, 2018). Persaingan yang ketat di dunia kerja, menginginkan sumber daya manusia yang memiliki keahlian lebih dibanding hanya memilki keahlian akademik saja. Salah satu keahlian tersebut adalah keahlian dalam bidang spasial. Selain memiliki keahlian dalam berpikir spasial, diharapkan mampu memiliki keahlian dalam mengenal lingkungan dan wilayah Indonesia. Hal inilah yang menjadi ciri khas atau karakter dari sumber daya manusia Indonesia dalam menghadapi persaingan antar Negara tersebut. Untuk itu, diperlukan instrumen yang dapat mengukur kemampuan berpikir spasialnya (Aliman, M., Ulfi, T., Lukman, S., Hi Muhammad, H., Negeri, S., Geografi, P., Kie Raha Ternate, S., \& Bumi Hijrah Tidore, 4 C.E.).

Definisi kecerdasan spasial merupakan kemampuan untuk melihat dengan tepat gambaran visual di sekitar mereka dan memperhatikan rincian kecil yang kebanyakan 
orang lain mungkin tidak memperhatikan. kecerdasan spasial memuat kemampuan seseorang untuk memahami secara lebih mendalam hubungan antara objek dan ruang. Kecerdasan spasial juga merupakan hasil dari proses kognitif yang dikelola oleh pikiran manusia (Winoto et al., 2020). Hal tersebut didasari karena dalam memilih suatu tindakan yang tepat untuk dilakukan tentu dibutuhkan kemampuan berpikir, di antaranya keterampilan dan kompetensi seseorang untuk memahami kaitan antar gejala, menilai, serta mempertimbangkan suatu penyelesaian masalah sehingga mampu mengambil solusi yang efisien ((Islamiati, Wahab Abdi, A., \& Desfandi, n.d.)et al., 2017).

Kecerdasan spasial merupakan hal yang menunjang pengembangan kreativitas mahasiswa dalam memunculkan ide dan gagasan. Hal ini dikarenakan kecerdasan spasial berkaitan dengan hal-hal visual termasuk desain yang menyangkut ruang, bentuk, dan warna (Artiningsih, A., Nugroho, P., Perdana, S. A. J., \& Khairunisa, 2019). Sehingga menunjukan bahwa kemampuan spasial merupakan salah satu kemampuan penting yang bermanfaat untuk kehidupan manusia, kemampuan spasial menyangkut kemampuan seseorang untuk memahami, menyimpan, mengingat, dan menciptakan gambaran mental tentang bentuk dan ruang.

Penelitian ini berbeda dengan penelitian terdahulu yang sejenis dalam konteks pengukuran kompetensi spasial seseorang. Seperti halnya penelitian pengembangan tes Spatial Literacy pada siswa SD Laboratorium UPI (Maharani \& Maryani, 2016), pengembangan instrument tes geo-literacy dan kecerdasan spasial pada siswa SMA di Kota dan Kabupaten bandung (Urfan, 2017), Penelitian pengembangan instrumen kecerdasan spasial tersebut bertujuan untuk mengukur kecerdasan spasial siswa dan hasil belajar siswa pada pelajaran geografi. Sedangkan penelitian ini merupakan pengembangan instrumen berpikir spasial yang tidak mengukur hasil belajar siswa namun mampu mengukur kemampuan berpikir spasial siswa tanpa harus mengikuti pembelajaran pada materi tertentu. Artinya, instrumen ini dapat digunakan pada mahasiwa. Penelitian ini diharapkan dapat memberikan gambaran secara objektif bagaimana literasi spasial mahasiswa, sehingga hal ini menjadi bahan evaluasi dalam meningkatkan literasi spasial mahasiwa, selain itu penelitian ini juga dapat menjadi bahan kajian peneliti lain terkait literasi spasial mahasiswa di perguruan tinggi.

\section{METODE}

Penelitian ini menggunakan penelitian kuantitatif, penelitian kuantitatif berupaya untuk mengungkap kebenaran dan prinsip universal dalam bentuk hubungan antar variabel atau fenomena. Ciri dalam penelitian kuantitatif yaitu teknik analisis datanya menggunakan teknik kuantitatif (statistika) secara objektif. Sedangkan jenis penelitian ini menggunakan metode survey. Menurut (Pinsonneault, A., \& Kraemer, 1993) bahwa penelitian survey dipandang sebagai metode untuk menggambarkan secara kuantitatif aspek-aspek spesifik dari populasi tertentu sehingga pengumpulan datanya dilakukan kepada sekolompok orang yang hasilnya dapat digeneralisasi kembali ke dalam suatu populasi tertentu. Penelitian survey sangat cocok digunakan dalam mengungkap bagaimana literasi spasial mahasiswa calon guru SD. Subjek dalam penelitian ini adalah mahasiswa pada program studi pendidikan guru sekolah dasar STKIP Muhammadiyah Kuningan, Jawa Barat yang berjumlah 160 orang. Instrumen yang digunakan dalam penelitian ini menggunakan data survey. Adapun surveynya dalam bentuk kuesioner yang dibuat dalam google form agar mudah diakses oleh mahasiswa.

Literasi spasial mahasiswa tercermin dari 4 karakteristik, yaitu pengimajinasian; pengkonsepan; penyelesaian masalah; pencarian pola(Uno, 2019)Secara rinci, indikator literasi spasial dapat dilihat pada tabel berikut ini. 
Tabel 1. Indikator Literasi Spasial

\begin{tabular}{|c|c|c|}
\hline No & Karakteristik & Indikator \\
\hline 1 & Pengimajinasian & $\begin{array}{l}\text { 1. Siswa mampu menggunakan bantuan gambar dalam } \\
\text { menyelesaikan permasalahan } \\
\text { 2. Siswa mampu menggambarkan penyelesaian masalah } \\
\text { dengan benar }\end{array}$ \\
\hline 2 & Pengkonsepan & $\begin{array}{l}\text { 1. Siswa mampu menyebutkan dengan benar konsep- } \\
\text { konsep yang berkaitan dengan permasalahan } \\
\text { 2. Siswa mampu menghubungkan antara data yang } \\
\text { diketahui dengan konsep yang telah dimiliki }\end{array}$ \\
\hline 3 & $\begin{array}{l}\text { Penyelesaian } \\
\text { Masalah }\end{array}$ & $\begin{array}{l}\text { 1. Siswa melihat masalah dari sudut pandang yang } \\
\text { berbeda-beda. } \\
\text { 2. Siswa mencetuskan banyak ide, banyak penyelesaian } \\
\text { masalah atau banyak pertanyaan dengan lancar. }\end{array}$ \\
\hline 4 & Pencarian Pola & $\begin{array}{l}\text { 1. Siswa mampu menemukan pola dalam menyelesaikan } \\
\text { permasalahan }\end{array}$ \\
\hline
\end{tabular}

Survey yang dibuat bertujuan untuk mengungkap secara detail tentang literasi spasial mahasiswa, adapun jenis surveynya menggunakan skala likert. Menurut (Sugiyono, 2018) bahwa skala likert digunakan sebagai alat untuk mengukur sikap, pendapat, dan persepsi individu atau sekolompok orang terhadap fenomena sosial. Adapun tabel skala likert disajikan di bawah ini.

\section{Tabel 2. Skala Likert}

\begin{tabular}{cc}
\hline Kriteria Penilaian & Skala Penilaian \\
\hline Sangat Setuju & 4 \\
Setuju & 3 \\
Tidak Setuju & 2 \\
Sangat Tidak Setuju & 1 \\
\hline \multicolumn{2}{c}{ Sumber (Creswell, 2010) }
\end{tabular}

Sementara itu, skor hasil penilaian survey yang telah dilakukan diperoleh dengan menggunakan perhitugan rumus berikut ini.

$$
\text { Rumus Index } \%=\frac{T \times P n}{Y} \times 100
$$

\section{Gambar 1. Rumus skor presentase responden}

Keterangan:

$T \quad$ : Total jumlah responden yang memilih

Pn : Pilihan angka skor Likert

Y : Skor Ideal

Sedangkan untuk interpretasi skornya berdasarkan Rumus interval berikut ini.

$$
\text { Rumus Interval }=\frac{100}{\text { Jumlah Skor (Likert) }}
$$

Gambar 2. Rumus skor presentase responden 
Dikarenakan jumlah skor likert pada survey penelitian ini adalah 4, maka sesuai rumus di atas perhitungannya adalah 100 dibagi 4 hasilnya 25, didapat kriteria interpretasi skor sebagai berikut.

Tabel 3. Kriteria interpretasi skor

\begin{tabular}{c|c}
\hline Presentase & Keterangan \\
\hline $0 \%-24,99 \%$ & Sangat Rendah \\
$25 \%-49,99 \%$ & Rendah \\
$50 \%-74,99 \%$ & Sedang \\
$75 \%-100 \%$ & Tinggi \\
\hline
\end{tabular}

Sumber (Creswell, 2010)

Hasil perhitungan di atas, menjadi dasar dalam menganalisis secara mendalam dan menyimpulkan bagaimana literasi spasial calon guru pada program studi pendidikan guru sekolah dasar di STKIP Muhammadiyah Kuningan.

HASIL DAN PEMBAHASAN

Kecerdasan Spasial merupakan kemampuan untuk berpikir dalam gambar serta mengubah, dan menciptakan kembali berbagai macam aspek dunia visual-spasial Data kecerdasan spasial mahasiswa PGSD STKIP Muhammadiyah Kuningan diukur menggunakan angket yang terdiri dari 12 item pernyataan.

Tabel 4. Item Pernyataan Angket Sesuai Indikator

\begin{tabular}{|c|c|c|c|c|c|c|}
\hline \multirow[b]{2}{*}{ No } & \multirow[b]{2}{*}{ Karakteristik } & \multirow[b]{2}{*}{ Pernyataan } & \multicolumn{4}{|c|}{ Keterangan } \\
\hline & & & $\begin{array}{l}\text { Sangat } \\
\text { Setuju }\end{array}$ & Setuju & $\begin{array}{l}\text { Tidak } \\
\text { Setuju }\end{array}$ & $\begin{array}{c}\text { Sangat } \\
\text { Tidak } \\
\text { Setuju }\end{array}$ \\
\hline \multirow[t]{3}{*}{1} & \multirow[t]{3}{*}{ Pengimajinasian } & $\begin{array}{l}\text { Saya suka menggambar kearifan } \\
\text { lokal di Kabupaten Kuningan }\end{array}$ & 15 & 123 & 22 & \\
\hline & & $\begin{array}{l}\text { Saya suka memanfaatkan media } \\
\text { gambar kearifan lokal sehingga } \\
\text { pembelajaran menyenangkan }\end{array}$ & 56 & 101 & 3 & \\
\hline & & $\begin{array}{l}\text { Belajar dengan memanfaatkan } \\
\text { bahan ajar berbasis kearifan lokal } \\
\text { membuat saya lebih aktif }\end{array}$ & 44 & 115 & 1 & \\
\hline \multirow[t]{5}{*}{2} & \multirow[t]{5}{*}{ Pengkonsepan } & $\begin{array}{l}\text { Saya suka melihat-lihat dan } \\
\text { memperhatikan buku yang } \\
\text { berilustrasi atau buku-buku } \\
\text { penuh gambar }\end{array}$ & 69 & 88 & 3 & \\
\hline & & $\begin{array}{l}\text { Saya senang memperhatikan } \\
\text { lokasi atau tempat kearifan lokal }\end{array}$ & 61 & 94 & 5 & \\
\hline & & $\begin{array}{l}\text { Saya senang mencari informasi } \\
\text { dari kearifan lokal di Kabupaten } \\
\text { Kuningan }\end{array}$ & 39 & 118 & 3 & \\
\hline & & $\begin{array}{l}\text { Saya suka mengunjungi } \\
\text { kebudayaan yang ada di } \\
\text { kabupaten kuningan }\end{array}$ & 26 & 112 & 22 & \\
\hline & & $\begin{array}{l}\text { Saya mendokumentasikan foto- } \\
\text { foto di lokasi kearifan lokal. }\end{array}$ & 43 & 100 & 17 & \\
\hline 3 & $\begin{array}{l}\text { Penyelesaian } \\
\text { Masalah }\end{array}$ & $\begin{array}{l}\text { Saya senang bercerita tentang } \\
\text { mimpi saya dan dapat } \\
\text { menunjukkan detil mimpi }\end{array}$ & 46 & 92 & 22 & \\
\hline
\end{tabular}




\begin{tabular}{|c|c|c|c|c|c|c|}
\hline \multirow[b]{2}{*}{ No } & \multirow[b]{2}{*}{ Karakteristik } & \multirow[b]{2}{*}{ Pernyataan } & \multicolumn{4}{|c|}{ Keterangan } \\
\hline & & & $\begin{array}{l}\text { Sangat } \\
\text { Setuju }\end{array}$ & Setuju & $\begin{array}{l}\text { Tidak } \\
\text { Setuju }\end{array}$ & $\begin{array}{c}\text { Sangat } \\
\text { Tidak } \\
\text { Setuju }\end{array}$ \\
\hline & & $\begin{array}{l}\text { Saya tertarik pada profesi yang } \\
\text { terkait dengan penggunaan } \\
\text { kecerdasan visual-spasial secara } \\
\text { optimal seperi pelukis, fotografer }\end{array}$ & 40 & 101 & 19 & \\
\hline & & $\begin{array}{l}\text { Saya merasa masih ada } \\
\text { beberapa kesulitan dalam } \\
\text { mengerjakan latihan/tes. }\end{array}$ & 27 & 113 & 19 & 1 \\
\hline 4 & Pencarian Pola & $\begin{array}{l}\text { Saya dapat merasakan pola-pola } \\
\text { sederhana dan mampu menilai } \\
\text { pola mana yang lebih bagus dari } \\
\text { pola lainnya. }\end{array}$ & 24 & 126 & 10 & \\
\hline
\end{tabular}

Akumulasi nilai angket selanjutnya dihitung nilai rata-ratanya dengan menggunakan rumus di atas, sehingga diperoleh nilai akhir sebagai acuan yang menggambarkan keragaman nilai kecerdasan spasial mahasiswa PGSD STKIP Muhammadiyah Kuningan.

Hasil perhitungan angket yang diberikan kepada 160 responden mengenai literasi spasial calon guru SD dapat dilihat pada tabel berikut ini.

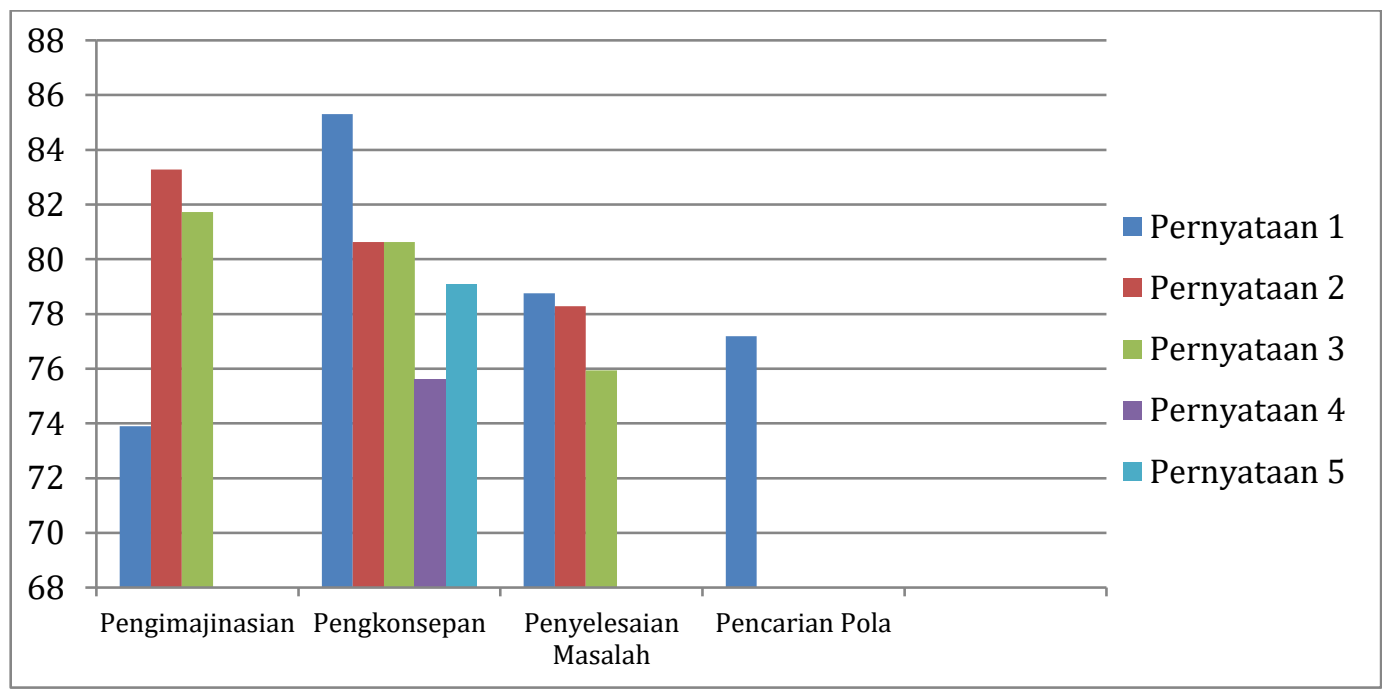

\section{Gambar 3. Diagram Hasil Perhitungan Angket}

Diagram di atas berisi tentang persentase angket dari 4 karakteristik yang terbagi dalam 12 pernyataan. Secara singkat, hasil rata-rata kemampuan literasi spasial calon guru SD di STKIP Muhammadiyah Kuningan dapat dilihat pada tabel 5 di bawah ini.

Tabel 5. Rata-rata Perhitungan Kemampuan Literasi Spasial

\begin{tabular}{clcc}
\hline No & Karakteristik & Persentase & Kategori \\
\hline 1 & Pengimajinasian & $79,81 \%$ & Tinggi \\
2 & Pengkonsepan & $80,25 \%$ & Tinggi \\
3 & Penyelesaian Masalah & $77,66 \%$ & Tinggi \\
4 & Pencarian Pola & $77,19 \%$ & Tinggi \\
& Rata-Rata & $\mathbf{7 8 , 7 3 \%}$ & Tinggi \\
\hline
\end{tabular}


Hasil penelitian ini menunjukkan bahwa Kategori tingkat kecerdasan spasial mahasiswa PGSD STKIP Muhammadiyah Kuningan secara umum berada pada kategori Tinggi dengan persentase berjumlah $78,73 \%$. Calon guru sekolah dasar yang menjadi responden sebelumnya telah melaksanakan perkuliahan dengan berbekal bahan ajar berbasil kearifan lokal. Berdasarkan hasil analisis data diketahui bahwa kategori tingkat kecerdasan spasial mahasiswa konsisten dari setiap karakteristik yang ditentukan. Pengimajinasian, pengkonsepan, penyelesaian masalah dan pencarian pola masingmasing berada pada kategori tinggi meskipun jumlah persentasenya beragam. (Gardner, 2000) menyebutkan bahwa anak-anak dengan ke- cerdasan visual-spatial yang tinggi cenderung berpikir secara visual. Mereka kaya dengan khayalan internal (internal imagery), sehingga cenderung imajinatif dan kreatif. Hasil penelitian juga mengungkapkan bahwa (Setiani, 2018) Mahasiswa calon guru mate- matika berdasarkan penelitian ini memiliki kecerdasan visual-spasial yang berbeda-beda, dan kemampuan literasi kuantitatifnya pula berbeda-beda.

Hasil penelitian oleh (Yusup, 2018) menunjukkan bahwa tidak terdapat banyak perbedaan antara siswa yang memiliki kecerdasan spasial tinggi dengan sedang dalam menyelesaikan masalah Geometri. Hasil yang ditemukan pada penelitian sebelumnya juga memberikan kesimpulan yang sama pada penelitian ini. Dalam banyak hal, siswa dengan kecerdasan spasial kategori sedang dan kategori tinggi memiliki kemampuan yang hampir sama namun pada siswa dengan kecerdasan spasial kategori sedang dibutuhkan beberapa stimulus yang dapat meningkatkan kecerdasan spasialnya agar menjadi lebih baik. Pada penelitian oleh Osronita dan Dewita (2017:42) membuktikan bahwa kecerdasan spasial meningkat setelah siswa mampu memahami dan menganalisis fenomena alam yang dipelajari langsung di luar ruang kelas. Hasil tersebut ditinjau dari kemampuan siswa menganalisis fenomena, memprediksi dan mendiskripsikan kembali fenomena yang terjadi dengan cukup jelas dan hasil evaluasi belajar yang berada di atas KKM. Artinya, kecerdasan spasial tentu dapat ditumbuhkan bahkan pada seseorang dengan tingkat kecerdasan spasial rendah sekalipun karena pada dasarnya sebagaimana yang telah dijelaskan pada beberapa teori, kecerdasan dan keahlian merupakan suatu kemampuan yang bisa saja diperoleh secara genetik namun juga dapat diperoleh melalui usaha keras jika terus dikembangkan dengan baik.

Hal tersebut juga dapat dijadikan sebagai rujukan bagi calon guru PGSD STKIP Muhammadiyah Kuningan untuk terus menggali kecerdasan spasial yang dimiliki siswa, salah satu diantaranya melalui penyusunan metode dan bahan ajar berbasis kecerdasan spasial. Kecerdasan spasial dapat dibangun secara kognitif, psikomotorik, dan afektif. Secara kognitif, kecerdasan spasial dapat dibangun dengan mengenalkan siswa kepada material spasial, misal dengan sketsa, denah, foto, peta, maket, dan film petualangan. Secara psikomotorik misalnya terbiasa mendokumentasikan aspek-aspek spasial meski hanya sebagai catatan pribadi, selain itu juga dapat berupa membuat deskripsi pelajaran secara rinci atau bahkan dilengkapi dengan gambar-gambar yang berkaitan dengan pelajaran. Secara afektif atau untuk membangun sikap, apresiasi siswa terhadap dunia spasial dapat dibangun dengan membiasakan siswa membaca grafik, simbol-simbol pada gambar bangun datar, ruang, juga termasuk membaca peta. Semakin aktif anak didik dalam mengembangkan kemampuan kognitif, afektif psikomotor melalui interaksi dengan guru, teman sejawat, serta bahan ajar dan lingkungan, maka semakin kaya dan semakin bermakna pengalaman belajar. Kecerdasan spasial atau yang lebih sederhananya disebut dengan kecerdasan ruang memungkinkan seseorang untuk berpikir secara akurat mengenai hubungan antar objek, ruang, interaksi dan fenomena yang terjadi di sekitarnya.

Kegiatan belajar dapat dikembangkan dengan berlandaskan kecerdasan spasial guna membentuk pola pikir siswa yang senantiasa memahami keruangan agar bijak 
dalam melakukan aktivitas serta dapat mengambil keputusan yang tepat terhadap permasalahan keruangan yang terjadi. Selain itu, kecerdasan spasial juga menghadirkan pengalaman-pengalaman yang terjadi di sekitar sebagai gambaran imajinasi yang dapat mengasah pemikiran sehingga dapat dituangkan sebagai suatu ide dalam melakukan tindakan dan perubahan yang lebih baik yang dapat diasah melalui kegiatan belajar. Setiap hal yang dipelajari siswa sebenarnya merupakan langkah untuk memberikan pemahaman kepada mereka mengenai apa saja yang sebenarnya mereka hadapi di lingkungan mereka secara nyata, termasuk langkah dan tindakan apa saja yang harus dilakukan ketika mereka menghadapi suatu permasalahan di sekitarnya. Untuk memahami itu, suatu potensi/kecerdasan yang terdapat pada seseorang dapat dikembangkan dan dimanfaatkan agar terjadinya kombinasi yang efektif antara potensi dan pengalaman menghadapi masalah sehingga mereka cakap dan dapat menemukan solusi yang lebih baik dalam menjalani kehidupan (Murtafi'ah \& Masfingatin, 2015). Literasi merupakan kemampuan yang perlu dikembangkan agar individu manpu memahami berbagai macam permasalahan sesuai dengan konteks yang terjadi (Pamungkas, 2017). Kemampuan literasi merupakan kemampuan yang sangat penting dalam menghadapi permasalahan sehari-hari, kemampuan spasial adalah kemampuan membayangkan, membanding, menduga, menentukan, menkonstruksi, mempresentasikan, dan menemukan informasi dari stimulus visual dalam konteks ruang. Berdasarkan hasil penelitian (Apecawati, 2015) juga menunjukan ada hubungan yang positif antara kemampuan spasial dengan prestasi belajar matematika baik pada kemampuan spasial total, maupun kemampuan spasial topologi dan kemampuan spasial euclidis. Kecerdasan visual-spasial merujuk pada kemampuan merangkai bagian atau visualisasi bagian secara mental dan dirangkai sesuai dengan pola-pola tiga dimensi yang diproses melalui pikirannya.

Peran guru atau calon guru sangat dibutuhkan untuk mengenali jenis kecerdasan yang dimiliki siswa sehingga dapat menentukan strategi, metode dan bahan mengajar yang efektif, khususnya dalam meningkatkan kecerdasan spasial (Maryani \& Maharani, 2015). Saat ini telah terdapat beberapa model pembelajaran yang dapat digunakan untuk menciptakan pembelajaran berbasis pengembangan kecerdasan spasial yang memanfaatkan alam sekitar dan kreativitas, namun tentu dengan adanya pembaharuan dan modifikasi yang terus membaik maka diharapkan guru terus dapat menciptakan model pembelajaran yang berwawasan lingkungan dan keruangan. Pembelajaran yang berhasil salah satunya tidak hanya melihat nilai yang dicapai siswa, namun juga turut memperhatikan bagaimana siswa dapat menerapkan apa yang telah dipelajarinya sebagai suatu cara memecahkan permasalahan nyata yang terjadi dalam kehidupan sehari-hari.

\section{SIMPULAN}

Hasil penelitian menunjukkan bahwa mahasiswa PGSD STKIP Muhammadiyah Kuningan yang memiliki kecerdasan spasial pada kategori tinggi yaitu sebesar $78,73 \%$ dengan rincian karakteristik pengimajinasian 79,81\%, pengkonsepan $80,25 \%$, penyelesaian masalah $77,66 \%$ dan pencarian pola sebesar $77,19 \%$. Kecerdasan spasial dapat ditingkatkan melalui metode-metode yang sesuai dengan perkembangan kognitif, psikomotorik, dan juga afektif. Dosen dapat ikut andil dalam memberikan fasilitas penunjang pembelajaran yang mendukung peningkatan kecerdasan khususnya kecerdasan spasial. Kategori tingkat kecerdasan spasial mahasiswa PGSD STKIP Muhammadiyah Kuningan secara umum berada pada kategori Tinggi dengan persentase berjumlah $78,73 \%$. Calon guru sekolah dasar yang menjadi responden sebelumnya telah melaksanakan perkuliahan dengan berbekal bahan ajar berbasil kearifan lokal. Berdasarkan hasil analisis data diketahui bahwa kategori tingkat kecerdasan spasial mahasiswa konsisten dari setiap karakteristik yang ditentukan. 
Pengimajinasian, pengkonsepan, penyelesaian masalah dan pencarian pola masingmasing berada pada kategori tinggi meskipun jumlah persentasenya beragam.

Saran yang dapat diberikan setelah dilakukannya penelitian ini adalah diharapkan bagi para peneliti selanjutnya dapat melakukan penelitian dengan objek penelitian yang belum pernah diteliti sebelumnya yang berkaitan dengan aspek spatial literacy, diharapkan penelitian ini dapat menambah referensi yang berkaitan dengan ruang khususnya pada aspek spatial literacy bagi calon guru pendidikan sekolah dasar.

\section{DAFTAR PUSTAKA}

Aliman, M., \& Mutia, T. (2018). INTEGRITAS KEBANGSAAN DALAM TES BERPIKIR SPASIAL Meta Analisis: Perkembangan Teori Struktural Fungsional dalam Sosiologi Pendidikan View project the influence of geography learning and spatial intelligence on environmental awareness View project.

Aliman, M., Ulfi, T., Lukman, S., Hi Muhammad, H., Negeri, S., Geografi, P., Kie Raha Ternate, S., \& Bumi Hijrah Tidore, U. (4 C.E.). Konstruksi Tes Kemampuan Berpikir Spasial Model Sharpe-Huynh. Georafflesia, 1.

Apecawati, L. D. (2015). Hubungan Kecerdasan Visual Spasial Dengan Kemampuan Menggambarkan Bentuk Molekul. Jurnal.Untan.Ac.ld, 2008, 1-11.

Artiningsih, A., Nugroho, P., Perdana, S. A. J., \& Khairunisa, M. U. (2019). Mapping community environmental sanitation issue using household spatial cognition: A case of Bulu Lor Subdistrict, Semarang, Indonesia. IOP Conference Series: Earth and Environmental Science, 313(1).

Creswell, J. W. (2010). Research Design: Pendekatan Kualitatif, Kuantitatif, dan Mixed. Pustaka Pelajar.

Gardner, H. E. (2000). Intelligence Reframed: Multiple Intelligences for the 21st Century (Kindle Edi). Amazon.com Services LLC.

Islamiati, Wahab Abdi, A., \& Desfandi, M. (n.d.). TINGKAT KECERDASAN SPASIAL SISWA SMPIT AL-AZHAR BANDA ACEH. Jurnal Pendidikan Geosfer, 11(1), 110.

Maryani, E., \& Maharani, W. (2015). Peningkatan Spatial Literacy Peserta Didik. Jurnal Pendidikan Geografi, Volume 15, 46-54.

Mayalagu, G., Jaafar, M., \& Kuok Choy, L. (2018). Validity of Module Geographic Information System-Spatial Thinking Skills (GIS-STS). International Journal of Engineering \& Technology, 1(1).

Murtafi'ah, W., \& Masfingatin, T. (2015). Proses Berpikir Mahasiswa dengan Kemampuan Spatial Intellegent Tinggi dalam Memecahkan Masalah Geometri. Jurnal IImiah Pendidikan Matematika, 6(1), 133-148.

Ningsih, S. (2016). Mengembangkan Kecerdasan Interpesonal Anak Usia Dini Melalui Permainan Tradisional (Studi Kasus di TK Al-Akhyar Purwakarta Kelompok B). Tunas Siliwangi, 2(No.1), 30-47. journal.stkipsiliwangi.ac.id/index.php/tunas-siliwangi/article/view/307/228

Pamungkas, A. S. (2017). Pengembangan Bahan Ajar Berbasis Literasi Pada Materi Bilangan Bagi Mahasiswa Calon Guru SD. Pendidikan Sekolah Dasar, 3(2), 228240

Santrock, J. W. (2007). Child Development (8th ed.). McGraw-Hill.

Setiani, Y., \& Rafianti, D. I. (2018). Pengaruh Tingkat Kecerdasan Visual-Spasial terhadap Literasi Kuantitatif Mahasiswa Calon Guru. Jurnal Pendidikan, 3(1).

Setiani, Y. (2018). Pengaruh Tingkat Kecerdasan Visual-Spasial terhadap Literasi Kuantitatif Mahasiswa Calon Guru Matematika. Kreano: Jurnal Matematika Kreatif- 
Inovatif, 9(1), 38-46. https://doi.org/10.15294/kreano.v9i1.12258.g7946

Uno, H. B. (2019). Teori Motivasi dan Pengukurannya Analisis di Bidang Pendidikan. Bumi Aksara.

Urfan, F. (2017). Pengaruh Lingkungan Sekolah Terhadap Kecerdasan Spasial Peserta Didik Melalui Affordance Dan Geo-Literacy Menggunakan Analisis Jalur. Jurnal Pendidikan, 4(2).

Yusup, F. (2018). Uji Validitas dan Reliabilitas. Jurnal Tarbiyah, Jurnal IImiah Kependidikan, 7(1), 17-23. 